ISSN: 2302-8556

E-Jurnal Akuntansi Universitas Udayana

Vol.23.2. Mei (2018): 1253-1276

DOI: https://doi.org/10.24843/EJA.2018.v23.i02.p17

\title{
Analisis Faktor-Faktor yang Mempengaruhi Kualitas Laporan Keuangan Pemerintah Daerah Kabupaten Karangasem
}

\author{
Tut Madiguna Agung ${ }^{1}$ \\ Gayatri $^{2}$
}

\author{
${ }^{1}$ Fakultas Ekonomi dan Bisnis Universitas Udayana (Unud), Bali, Indonesia \\ email: madigunaa@gmail.com / Telp: 085748151249 \\ ${ }^{2}$ Fakultas Ekonomi dan Bisnis Universitas Udayana (Unud), Bali, Indonesia
}

\begin{abstract}
ABSTRAK
Fenomena di dalam perkembangan sektor publik di Indonesia adalah menguatnya tuntutan atas kualitas laporan keuangan pemerintah. Laporan keuangan pemerintah yang dihasilkan harus memenuhi karakteristik kualitatif pada Peraturan Pemerintah Nomor 71 Tahun 2010. Penelitian dilakukan pada SKPD Kabupaten Karangasem yang berjumlah 43 SKPD di lingkungan Pemerintah Kabupaten Karangasem. Jumlah sampel yang diambil sebanyak 129 orang. Teknik analisis yang digunakan adalah analisis regresi linier berganda. Hasil penelitian menunjukkan bahwa gaya kepemimpinan, kompetensi sumber daya manusia, sistem pengendalian internal, komitmen organisasi dan pemanfaatan teknologi informasi berpengaruh positif dan signifikan terhadap kualitas laporan keuangan Pemerintah Daerah. Peneliti selanjutnya diharapkan agar dapat menambah faktor-faktor lain yang mungkin dapat mempengaruhi kualitas laporan keuangan Pemerintah daerah, misalnya menambah variabel independen atau variabel moderasi seperti penerapan standar akuntansi pemerintahan. Selain itu, agar hasil penelitian dapat digunakan secara luas, maka peneliti selanjutnya sebaiknya dapat menambah subjek penelitian dan tidak hanya terbatas pada satu Kabupaten saja.

Kata kunci : gaya kepemimpinan, kompetensi SDM, sistem pengendalian internal, komitmen organisasi, pemanfaatan teknologi informasi, kualitas laporan keuangan
\end{abstract}

\footnotetext{
ABSTRACT

The phenomenon in the development of the public sector in Indonesia is the strengthening of the demand for the quality of government financial reports. The resulting government financial report must meet the qualitative characteristics of Government Regulation No. 71 of 2010. The study was conducted on SKPD Kabupaten Karangasem which amounted to 43 SKPD in the Government of Karangasem Regency. The number of samples taken as many as 129 people. The analysis technique used is multiple linear regression analysis. The results showed leadership style, human resource competence, internal control system, organizational commitment and utilization of information technology have a positive and significant impact on the quality of local government financial statements. The researcher is then expected to be able to add other factors that may affect the quality of local government financial statements, such as adding independent variables or moderating variables such as the application of government accounting standards.

Keywords: leadership style, human resource competence, internal control system, organizational commitment, utilization of information technology, quality of financial report
} 


\section{PENDAHULUAN}

Fenomena kualitas laporan keuangan pemerintah di Indonesia merupakan suatu hal yang menarik untuk dikaji lebih lanjut. Seiring dengan perkembangan akuntansi sektor publik di Indonesia, maka wujud pertanggung jawaban kepada masyarakat atas kinerja pemerintah menjadi suatu tuntutan yang umum. Fenomena yang terjadi dalam perkembangan sektor publik di Indonesia adalah menguatnya tuntutan atas kualitas informasi laporan keuangan pemerintah (Nurillah, 2014). Para pemangku kepentingan memerlukan informasi-informasi yang bermanfaat dan memiliki nilai untuk digunakan dalam pengambilan keputusan (Suwardjono, 2005). Informasi yang bermanfaat adalah informasi yang dapat digunakan oleh para pemangku kepentingan dalam melakukan pengambilan keputusan.

Informasi-informasi yang disajikan oleh pemerintah daerah harus diperhatikan dengan sebaik-baiknya sebab informasi-informasi tersebut akan digunakan untuk pengambilan berbagai keputusan seperti perencanaan dan pengendalian (Husna, 2013).

\section{Tabel 1.}

Laporan Hasil Pemeriksaan Keuangan

\begin{tabular}{llllllllll}
\hline Entitas & $\mathbf{2 0 0 8}$ & $\mathbf{2 0 0 9}$ & $\mathbf{2 0 1 0}$ & $\mathbf{2 0 1 1}$ & $\mathbf{2 0 1 2}$ & $\mathbf{2 0 1 3}$ & $\mathbf{2 0 1 4}$ & $\mathbf{2 0 1 5}$ & $\mathbf{2 0 1 6}$ \\
\hline Prov. Bali & TMP & WDP & WDP & WDP & WDP & TW & WTP & WTP & WTP \\
Kab. Badung & TMP & WDP & WDP & WDP & WTP & TMP & WTP & WTP & WTP \\
Kab. Bangli & WDP & WDP & WDP & WDP & WDP & WDP & WDP & WDP & WTP \\
Kab. Buleleng & WDP & WDP & TMP & WDP & WDP & WDP & WTP & WTP & WTP \\
Kab. Gianyar & WDP & WDP & WDP & WDP & WDP & WDP & WTP & WTP & WTP \\
Kab. Jembrana & TMP & TW & TW & WDP & WDP & WDP & WTP & WTP & WTP \\
Kab. Karangasem & WDP & WDP & TMP & WDP & WDP & WDP & WDP & WTP & WTP \\
Kab. Klungkung & WDP & WDP & WDP & WDP & WDP & WDP & WDP & WTP & WTP \\
Kab. Tabanan & WDP & WDP & WDP & WDP & TMP & WDP & WTP & WTP & WTP \\
Kota Denpasar & WDP & WDP & WDP & WDP & WTP & WTP & WTP & WTP & WTP \\
\hline Sumber: Data diolah, 2017 & & & & & & & &
\end{tabular}


ISSN: 2302-8556

E-Jurnal Akuntansi Universitas Udayana

Vol.23.2. Mei (2018): 1253-1276

Berdasarkan Tabel 1 menunjukkan bahwa belum semua kabupaten/kota di

Provinsi Bali berdasarkan laporan hasil pemeriksaan keuangan. Hasil ini menunjukkan masih belum maksimalnya kinerja masing-masing daerah tersebut. Rendahnya potensi atas pendapatan daerah berkontribusi terhadap penilaian BPK atas laporan keuangan pemerintah. Penyusunan laporan keuangan yang baik harus memenuhi karakteristik laporan keuangan. Berdasarkan hasil temuan BPK dalam Ikhtisar Hasil Pemeriksaan BPK-RI semester II Tahun 2014 diketahui bahwa Pemerintah Kabupaten Karangasem mengalami penurunan pendapatan daerah yang paling besar dibandingkan dengan Kabupaten Bangli dan Klungkung.

Permasalahan aset paling banyak ditemukan pada sektor retribusi pajak daerah yang memang pengelolaannya masih kurang maksimal. Setiap tahun Pemerintah Kabupaten Karangasem melalui Dinas terkait terus mengupayakan perbaikan, namun lemahnya sumber daya manusia yang mengelola membuat penataan aset semakin rumit. Predikat tersebut menyebabkan Pemerintah Kabupaten Karangasem harus terus berupaya meningkatkan segala aspek dalam pemerintahan seperti kepemimpinan dalam organisasi, kualitas sumber daya manusia, komitmen organisasi, sistem pengendalian intern, dan pemanfaatan teknologi informasi sesuai dengan standar.

Sehingga apa yang diperoleh atas opini laporan keuangan Pemerintah Daerah Kabupaten Karangasem dapat dipertahankan, seperti tahun 2016 Pemerintah Kabupaten Karangasem memperoleh predikat WTP. Dengan peningkatan opini ini dari tahun ke tahun diharapkan Pemerintah Kabupaten Karangasem dapat 
mempertahankan opini tersebut dan meningkatkan kompetensi dalam mengelola aset serta melakukan perbaikan kinerja didalam pemerintahannya khususnya mengenai laporan keuangan.

Berdasarkan uraian tersebut peneliti tertarik melakukan penelitian pada Pemerintah Kabupaten Karangasem khususnya mengenai kualitas laporan keuangan. Berdasarkan fenomena dari opini laporan keuangan, Pemerintah Kabupaten Karangasem mengindikasikan adanya upaya untuk terus meningkatkan kualitas laporan keuangan, serta dari sisi kepemimpinan, kualitas sumber daya manusia, sistem pengendalian intern, pemanfaatan teknologi informasi serta komitmen organisasi pegawai yang semakin meningkat.

Sumber daya manusia adalah orang yang siap, mau, dan mampu memberikan sumbangan dalam usaha pencapaian tujuan organisasional (Hullah dkk. 2012). Dalam hal ini adanya kompetensi sumber daya manusia mendasari seseorang mencapai kinerja yang tinggi dalam pekerjaan memiliki peranan yang sangat penting untuk merencanakan, melaksanakan, dan mengendalikan entitas yang bersangkutan (Wati dkk, 2014). Kualitas laporan keuangan juga dapat ditentukan oleh faktor kepemimpinan karena gaya kepemimpinan yang diterapkan akan mempengaruhi kinerja bawahannya. Pemimpin yang baik sebenarnya pemimpin yang mau berkorban dan peduli untuk orang lain serta bersifat melayani. Gaya kepemimpinan adalah pola tingkah laku yang dirancang untuk mengintregasikan tujuan organisasi dengan tujuan individu untuk tujuan tertentu (Heidjracman, 2002:224). 
ISSN: 2302-8556

E-Jurnal Akuntansi Universitas Udayana

Vol.23.2. Mei (2018): 1253-1276

Gaya kepemimpinan menunjukkan cara atau sikap bagaimana seorang pemimpin memberikan pengaruh kepada anggotanya untuk dapat mencapai tujuan bersama. Sikap dan perilaku anggota organisasi tercermin dari bagaimana gaya kepemimpinan seorang pemimpin sehingga gaya kepemimpinan yang baik yang dapat memotivasi anggotanya akan menjadikan organisasi lebih mudah dalam mencapai tujuannya dan anggota organisasi akan dapat menunjukkan kinerja yang lebih baik. Pengendalian Intern merupakan hal yang berpengaruh terhadap kualitas laporan keuangan, (Sari, 2014). Selain hal tersebut, hal lain yang juga harus diperhatikan oleh pemerintah daerah dalam menciptakan laporan keuangan yang berkualitas yaitu komitmen organisasi. Komitmen menunjukkan loyalitas seorang karyawan, serta keinginan untuk aktif terlibat dalam organisasi dan berusaha membangun organisasi dengan nilai-nilai yang positif (Vandenberg, 1992).

Komitmen menunjukkan keinginan seseorang untuk bertahan dalam organisasi serta ikut terlibat dalam pengambilan keputusan dalam usaha untuk mencapai tujuan organisasi sehingga akan berusaha menciptakan kinerja yang baik. Indriasari (2008) serta Widyaningrum dan Rahmawati (2010), menyatakan ada beberapa faktor yang berpengaruh pada nilai laporan keuangan yaitu sumber daya manusia, teknologi informasi dan pengendalian intern. Sedangkan penelitian oleh Muhhamad Salleh (2012) menyatakan sumber daya manusia, pengendalian intern dan pemanfaatan teknologi informasi tidak memiliki pengaruh pada kualitas laporan keuangan. 
Hal tersebut disebabkan oleh belum adanya kejelasan mengenai tugas-tugas dan fungsi dari staf akuntansi yang ada, serta masih kurangnya diadakan pelatihanpelatihan tentang penyusunan laporan keuangan sesuai dengan Standar Akuntansi Keuangan (SAK). Masih lemahnya sistem pengendalian intern yang berkaitan dengan kegiatan penyusunan laporan keuangan serta rendahnya kesadaran pemerintah untuk memperbaharui aplikasi teknologi informasi sesuai dengan revisi standar terbaru SAK serta masih adanya transaksi yang tidak terkomputerisasi menjadi alasan kenapa tidak adanya pengaruh pengendalian intern dan pemanfaatan teknologi informasi pada kualitas laporan.

Gaya kepemimpinan yang diterapkan oleh atasan juga dapat mempengaruhi perilaku dan kinerja bawahan yang dapat mempengaruhi kualitas kinerja karyawan itu sendiri. Gaya kepemimpinan merupakan sikap atau perilaku seseorang dalam mempengaruhi sikap perilaku anggota organisasinya (Nawawi, 2003:113). Menurut hasil penelitian (Herniyasa, dkk 2014), menyatakan bahwa gaya kepemimpinan yang diterapkan seorang atasan memberikan pengaruh positif terhadap kualitas laporan keuangan. Adanya output berupa laporan keuangan yang berkualitas tidak terlepas dari dukungan kinerja dan perilaku pegawai. Perilaku pegawai yaitu terkait dengan adanya komitmen terhadap organisasinya untuk memberikan hasil kinerja yang baik serta dapat memberikan laporan pertanggung jawaban yang berkualitas (Ratifah dkk. 2012).

Sukirman dkk. (2014) menyatakan komitmen organisasi tidak memiliki pengaruh pada kualitas laporan keuangan. Sedangkan penelitian yang dilakukan oleh 
ISSN: 2302-8556

E-Jurnal Akuntansi Universitas Udayana

Vol.23.2. Mei (2018): 1253-1276

Sugandi (2013) menyatakan bahwa komitmen organisasi berpengaruh pada kualitas laporan keuangan. Seorang pegawai dengan komitmen yang tinggi akan berusaha menunjukkan bahwa pegawai tersebut memiliki kinerja yang baik dan terus berusaha untuk melakukan peningkatan terhadap kinerjanya. Berdasarkan uraian diatas, pengkajian kembali variabel-variabel pada penelitian ini didasari dengan adanya ketidakkonsistenan hasil dari beberapa penelitian yang telah dilakukan sebelumnya.

Gaya kepemimpinan adalah sikap atau cara yang dipergunakan oleh seseorang untuk mempengaruhi sikap dan perilaku orang lain (Khairina, 2012). Seorang pimpinan harus dapat menciptakan iklim kerja yang positif sehingga mampu melakukan pengembangan terhadap diri anggotanya serta nantinya diharapkan dapat mningkatkan kinerja organisasi (Trisnaningsih, 2007). Pemimpin merupakan pemeran utama yang akan menentukan arah keberhasilan dari suatu organisasi. Gaya kepemimpinan yang dimiliki oleh seorang pemimpin dapat berpengaruh pada sikap dan perilaku anggotanya dalam menyelesaikan tugas-tugasnya sehingga berpengaruh pula pada hasil kerja anggota organisasinya. Semakin baik cara memimpin seorang pimpinan dimana karyawan tersebut bekerja, maka akan semakin mempengaruhi kinerja dari seorang karyawan tersebut.

Menurut penelitian yang dilakukan oleh (Herniyasa dkk., 2014) menemukan bahwa gaya kepemimpinan berpengaruh positif terhadap kualitas laporan keuangan. Berdasarkan dari uraian diatas maka dirumuskan hipotesis sebagai berikut:

$\mathrm{H}_{1}$ : Gaya kepemimpinan berpengaruh positif terhadap kualitas laporan keuangan pemerintah daerah 
Kompetensi sumber daya manusia sangat terkait dengan kinerja yang dihasilkan. Kompetensi sumber daya manusia berperan dalam menciptakan laporan keuangan yang berkualitas. Kurangnya keahlian yang dimiliki serta rendahnya kompetensi yang dimiliki akan berdampak pada kualitas laporan keuangan yang dihasilkan serta dikhawatirkan akan adanya kekeliruan pada proses penyusunan laporan keuangan tersebut (Soimah, 2014). Penelitian oleh (Nurrilah, 2014), (Roviyantie, 2011), (Yosefrinaldi, 2013), (Ariesta, 2013), (Dellano dan Deviani, 2013), menunjukkan hasil kompetensi sumber daya manusia berpengaruh positif pada kualitas laporan keuangan. Kompetensi sumber daya manusia yang baik akan dapat menciptakan kualitas laporan keuangan yang baik pula. Hipotesis kedua yang diajukan dalam penelitian ini adalah:

$\mathrm{H}_{2}$ : Kompetensi sumber daya manusia berpengaruh positif terhadap kualitas laporan keuangan pemerintah daerah

Adanya sistem pengendalian internal yang baik diharapkan dapat meningkatkan keandalan data akuntansi yang dihasilkan (Warren et al. 2005). Melalui sistem pengendalian internal yang baik juga akan mengurangi resiko adanya kekeliruan maupun kesalahan-kesalahan dalam penyusunan laporan keuangan sehingga mampu menciptakan kualitas laporan keuangan yang baik. Sistem pengendalian internal yang dirancang dengan baik juga harus sejalan dengan bagianbagian dan fungsi-fungsi terkait yang dapat berintegrasi dengan masing-masing tugas dan tanggung jawabnya sehingga sistem yang telah dirancang dapat berjalan dengan baik pula. 
ISSN: 2302-8556

Adanya penyimpangan-penyimpanga serta masih adanya opini "tidak wajar dan/atau disclaimer" dapat disebabkan oleh lemahnya sistem pengendalian internal pemerintah terkait (Nurillah, 2014). Penelitian oleh (Nurillah, 2014) menemukan hasil sistem pengendalian internal berpengaruh pada kualitas laporan keuangan. Penelitan tersebut didukung dengan penelitian oleh (Sugandi, 2013), (Yosefrinaldi, 2013) yang menemukan hasil sistem pengendalian internal memiliki pengaruh signifikan pada kualitas laporan keuangan pemerintah daerah. Hipotesis ketiga dalam penelitian ini berdasarkan hal yang telah dipaparkan tersebut yaitu:

$\mathrm{H}_{3}$ : Sistem pengendalian intern berpengaruh positif terhadap kualitas laporan keuangan pemerintah daerah.

Komitmen organisasi menunjukkan loyalitas seorang anggota organisasi untuk tetap bertahan dalam organisasi serta keinginan untuk berusaha memberikan hasil kerja yang terbaik bagi kepentingan organisasi itu sendiri (Luthan, 2006:249). Menurut (Cherington, 1998) komitmen organisasi dinyatakan sebagai nilai personal, yang kadang-kadang mengacu sebagai sikap loyal pada perusahaan. Semakin tinggi komitmen organisasi seorang karyawan maka semakin tinggi loyalitas karyawan terhadap perusahaan. Tingginya loyalitas maka diharapkan akan meningkatkan motivasi kinerja karyawan dan memiliki pengendalian internal dalam diri untuk memajukan organisasi yang dijalankan.

Menurut penelitian yang dilakukan (Sugandi, 2013) menemukan hasil bahwa komitmen organisasi memberikan pengaruh signifikan terhadap keterandalan pelaporan keuangan. Sedangkan menurut penelitian yang dilakukan oleh (Nopprial 
,2015) menemukan hasil bahwa komitmen organisasi berpengaruh positif pada kualitas laporan keuangan. Hipotesis keempat berdasarkan uraian tersebut adalah:

$\mathrm{H}_{4}$ : Komitmen organisasi berpengaruh positif terhadap kualitas laporan keuangan pemerintah daerah

Teknologi informasi yang semakin maju akan memberikan dampak positif jika dapat dimanfaatkan dengan baik. Adanya berbagai teknologi informasi ini dapat memudahkan pihak-pihak yang terkait dengan penyusunan laporan keuangan dalam melakukan pengelolaan data dan informasi dengan lebih cepat serta lebih akurat dan meminimalisir adanya kekeliruan (Indriasari, 2008). Pemanfaatan teknologi ini berperan penting dalam memudahkan pengelolaan data serta informasi sehingga diharapkan dapat memaksimalkan kualitas informasi yang dihasilkan (Jogiyanto, 2006). Penelitian sebelumnya oleh (Indriasari, 2008) dan (Widyaningrum, 2010) memperoleh hasil adanya hubungan positif pemanfaatan teknologi informasi dengan kualitas laporan keuangan. Sehingga hipotesis kelima dalam penelitian ini yaitu:

$\mathrm{H}_{5}$ : Pemanfaatan teknologi informasi berpengaruh positif terhadap kualitas laporan keuangan pemerintah daerah.

\section{METODE PENELITIAN}

Penelitian ini digolongkan pada penelitian yang menggunakan pendekatan kuantitatif berbentuk asosiatif. Pendekatan yang dilakukan dalam penelitian ini adalah pendekatan kuantitatif dengan bentuk asosiatif, yaitu untuk mengetahui pengaruh gaya kepemimpinan, kompetensi sumber daya manusia, sistem pengendalian intern, komitmen organisasi, dan pemanfaatan teknologi informasi, pada kualitas laporan 
ISSN: 2302-8556

E-Jurnal Akuntansi Universitas Udayana

Vol.23.2. Mei (2018): 1253-1276

keuangan pemerintah daerah. Berikut ini adalah kerangka pemikiran yang dituangkan dalam desain penelitian pada Gambar 1 .

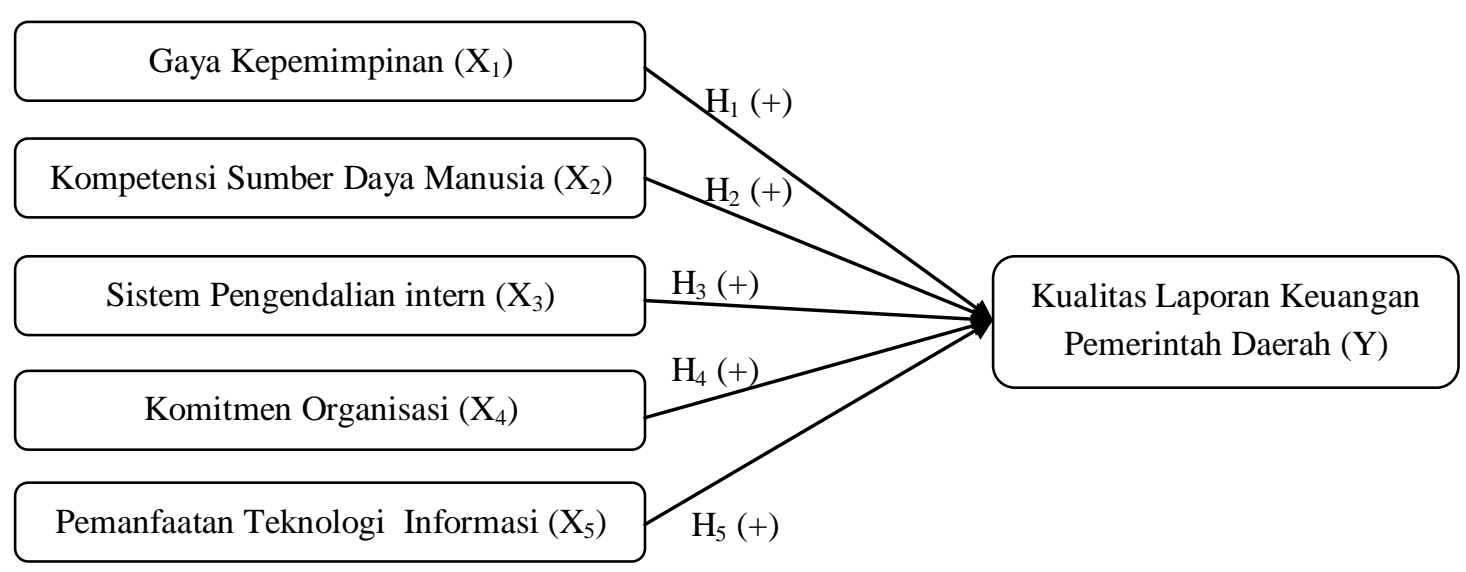

Gambar 1.

Sumber: Data diolah, 2017

\section{Desain Penelitian}

Penelitian ini dilakukan pada SKPD Kabupaten Karangasem yang berjumlah

43 SKPD di lingkungan Pemerintah Kabupaten Karangasem. Sesuai dengan pokok masalah dan hipotesis yang diajukan, variabel-variabel yang dianalisis dalam penelitian ini dikelompokkan menjadi Variabel bebas (variabel independen) dan Variabel terikat (variabel dependen). Variabel bebas merupakan variabel yang mempengaruhi atau menjadi sebab perubahan atau timbulnya variabel dependen (Sugiyono, 2012:59). Variabel bebas yang digunakan adalah gaya kepemimpinan, kompetensi sumber daya manusia, sistem pengendalian intern, komitmen organisasi, dan pemanfaatan teknologi informasi. Variabel terikat yang digunakan adalah kualitas laporan keuangan pemerintah daerah.

Jenis data yang digunakan dalam penelitian ini adalah data kualitatif dan data kuantitatif. Data kualitatif yaitu berupa nama SKPD kabupaten karangasem. Data 
kuantitatif yang digunakan adalah data jumlah pegawai yang bekerja pada bagian keuangan pada massing-masing SKPD dan hasil kuisioner yang merupakan jawaban responden yang diukur dengan skala likert. Sumber data dari penelitian ini adalah data primer dan data sekunder. Data primer yang digunakan adalah jawaban reponden dari kuesioner penelitian. Data sekunder yang digunakan dalam penelitian ini berupa daftar SKPD kabupaten Karangasem. Metode penentuan sampel yang digunakan dalam penelitian ini adalah metode purposive sampling. Metode purposive sampling adalah teknik pengambilan sampel sumber data dengan kriteria yang telah ditentukan (Sugiyono 2014:116). Adapun yang menjadi kriteria responden dalam penelitian adalah kepala bagian keuangan dan dua staf pegawai bagian keuangan yang bekerja pada SKPD kabupaten Karangasem

Metode pengumpulan data dilakukan dengan menggunakan kuisioner. Dalam pengumpulan data ini penulis terjun langsung ke lokasi penelitian dan memberikan kuisioner secara langsung kepada responden untuk diisi. Dari data yang diperoleh dari metode ini merupakan hasil pengisian kuisioner oleh responden mengenai seputar variabel yang akan diteliti. Pada penelitian ini terlebih dahulu dilakukan uji validitas dan realiabilitas instrumen penelitian yaitu berupa hasil kuesioner sehingga dapat diketahui apakah jawaban responden tersebut telah dijawab dengan benar atau tidak. Model regresi yang baik dapat dilihat dari medel regresi yang terbebas dari masalah normalitas, multikolinearitas, serta masalah heteroskedasitas. Oleh karena itu, maka sangat diperlukan pengujian terhadap model regresi yang akan digunakan didalam penelitian. 
ISSN: 2302-8556

E-Jurnal Akuntansi Universitas Udayana

Vol.23.2. Mei (2018): 1253-1276

Analisis regresi linear berganda digunakan sebagai teknik analisis data dalam penelitian ini. Model regresi linear berganda dalam penelitian ini ditunjukkan dengan persamaan sebagai berikut.

$Y=\alpha+\beta_{1} X_{1}+\beta_{2} X_{2}+\beta_{3} X_{3}+\beta_{4} X_{4}+\beta_{5} X_{5}+e$

Keterangan :

$\mathrm{Y}=$ kualitas laporan keuangan

$\alpha=$ konstanta

$\beta_{1}=$ koefisien regresi gaya kepemimpinan

$\beta_{2}=$ koefisien regresi kualitas sumber daya manusia

$\beta_{3}=$ koefisien regresi komitmen organisasi

$\beta_{4}=$ koefisien regresi sistem pengendalian intern

$\beta_{5}=$ koefisien regresi pemanfaatan teknologi informasi

$\mathrm{X}_{1}=$ gaya kepemimpinan

$\mathrm{X}_{2}=$ kualitas sumber daya manusia

$\mathrm{X}_{3}=$ komitmen organisasi

$\mathrm{X}_{4}=$ sistem pengendalian intern

$\mathrm{X}_{5}=$ pemanfaatan teknologi informasi

$E=$ error

\section{HASIL DAN PEMBAHASAN}

Uji validitas digunakan untuk mengetahui valid tidaknya kuesioner dalam pengumpulan data. Indikator variabel dikatakan valid apabila harga $r_{\text {hitung }}>r_{\text {tabel }}$ pada nilai signifikansi 5 persen. Berdasarkan hasil uji validitas pada penelitian ini seluruh item pertanyaan menunjukkan nilai $r_{\text {hitung }}>r_{\text {tabel }}$ pada nilai signifikansi 5 persen. Maka dapat disimpulkan bahwa seluruh indikator variabel dalam penelitian ini adalah valid, sehingga dapat digunakan sebagai instrumen penelitian.

Suatu variabel dapat dikatakan reliabel jika memberikan nilai Cronbach Alpha lebih besar atau diatas dari 0,70 (Ghozali, 2009:45). Hasil uji reliabilitas pada penelitian ini menunjukkan bahwa seluruh instrumen penelitian memiliki koefisien 
Cronbach's Alpha lebih dari 0,70. Maka dapat disimpulkan bahwa seluruh indikator variabel dalam penelitian ini adalah reliabel, sehingga dapat digunakan sebagai instrumen penelitian.

Berdasarkan hasil uji normalitas pada penelitian ini diperoleh nilai Kolmogorov Sminarnov (K-S) sebesar 0,913, sedangkan nilai Asymp. Sig. (2-tailed) sebesar 0,375 . Hal tersebut menunjukkan model penelitian ini berdistribusi normal karena Asymp. Sig. (2-tailed) yang diperoleh 0,375 lebih besar dari nilai alpha 0,05. Hasil uji multikolinearitas penelitian ini diperoleh nilai tolerance dan VIF dari seluruh variabel menunjukkan bahwa nilai tolerance untuk setiap variabel lebih besar dari $10 \%$ dan nilai VIF lebih kecil dari 10 yang berarti model persamaan regresi bebas dari multikolinearitas.

Hasil uji heteroskedastisitas pada penelitian ini diperoleh nilai signifikansi masing-masing variabel bebas dalam penelitian ini lebih besar dari 0,05 yang memiliki arti tidak adanya pengaruh antara variabel bebas terhadap absolute residual. Sehingga model yang dibuat terbebas gejala heteroskedastisitas. Berdasarkan hasil uji normalitas, uji multikolinearitas dan uji heteroskedastisitas pada penelitian ini maka dapat dinyatakan bahwa model regresi penelitian ini lolos uji asumsi klasik.

Pengujian data dalam penelitian ini menggunakan teknik analisis regresi linier berganda. Hasil uji analisis regresi linear berganda diperoleh hasil yang ditunjukan pada Tabel 2 berikut. 
ISSN: 2302-8556

E-Jurnal Akuntansi Universitas Udayana

Vol.23.2. Mei (2018): 1253-1276

Tabel 2.

Hasil Analisis Regresi Linier Berganda

\begin{tabular}{llll}
\hline Variabel & $\begin{array}{l}\text { Nilai } \\
\text { Koefisien } \\
\text { Regresi }\end{array}$ & $\begin{array}{l}\text { t } \\
\text { hitung }\end{array}$ & $\begin{array}{l}\text { Nilai } \\
\text { Signifikansi }\end{array}$ \\
& 0.165 & 2.264 & 0.025 \\
\hline Gaya Kepemimpinan $\left(\mathrm{X}_{1}\right)$ & 0.196 & 2.221 & 0.028 \\
Kompetensi Sumber Daya Manusia $\left(\mathrm{X}_{2}\right)$ & 0.228 & 2.900 & 0.004 \\
Sistem Pengendalian Internal $\left(\mathrm{X}_{3}\right)$ & 0.150 & 2.070 & 0.041 \\
Komitmen Organisasi $\left(\mathrm{X}_{4}\right)$ & 0.238 & 2.500 & 0.014 \\
Pemanfaatan Teknologi Informasi $\left(\mathrm{X}_{5}\right)$ & & & 0,633 \\
R Square & & & 0,618 \\
Adjusted R Square & & & 42,429 \\
F Statistik & & & 0,000 \\
Signifikansi & & & \\
\hline Suber: Dan & & & \\
\hline
\end{tabular}

Sumber : Data diolah, 2017

Berdasarkan hasil analisis regresi linier berganda seperti yang disajikan pada

Tabel 2, maka dapat dibuat persamaan strukturalnya sebagai berikut :

$\mathrm{Y}=\alpha+0,165 \mathrm{X} 1+0,196 \mathrm{X} 2+0,228 \mathrm{X} 3+0,150 \mathrm{X} 4+0,238 \mathrm{X} 5+\mathrm{e}$

Hasil koefisien determinasi pada Tabel 2 menunjukkan nilai determinasi total

sebesar 0,633 mempunyai arti bahwa sebesar 63,3\% variasi Kualitas Laporan Keuangan Pemerintah Daerah dipengaruhi oleh variasi Gaya Kepemimpinan, Kompetensi Sumber Daya Manusia, Sistem Pengendalian Internal, Komitmen Organisasi dan Pemanfaatan Teknologi Informasi sedangkan sisanya sebesar 36,7\% dijelaskan oleh faktor lain yang tidak dimasukkan ke dalam model.

Berdasarkan Tabel 2 menunjukkan nilai F hitung lebih besar dari F tabel yakni 42,429 > 2,29, dengan nilai signifikansi $0,000<0,05$, maka $\mathrm{H}_{0}$ ditolak. Hal ini berarti bahwa gaya kepemimpinan, kompetensi sumber daya manusia, sistem pengendalian internal, komitmen organisasi dan pemanfaatan teknologi informasi secara simultan berpengaruh signifikan terhadap Kualitas Laporan Keuangan Pemerintah Daerah. 
Gaya kepemimpinan adalah cara seorang pemimpin dalam memberikan pengaruh pada anggotanya (Khairina, 2011). Pemimpin merupakan pemeran utama yang akan menentukan arah keberhasilan dari suatu organisasi. Gaya kepemimpinan yang dimiliki oleh seseorang akan mempengaruhi sikap dan perilaku anggota organisasi sehingga berpengaruh pula pada kinerja anggota organisasi dalam melaksanakan tugas-tugas dan tanggung jawabnya (Trisnaningsih, 2007). Penelitian ini menunjukkan hasil bahwa gaya kepemimpinan berpengaruh positif pada kualitas laporan keuangan pemerintah daerah. Artinya, semakin baik cara memimpin seorang pimpinan dalam sebuah organisasi, maka akan kualitas laporan keuangan semakin meningkat. Penelitian ini sejalan dengan penelitian oleh Herniyasa dkk. (2014) yang menemukan hasil gaya kepemimpinan berpengaruh positif pada kualitas laporan keuangan.

Hasil pengujian penelitian ini menunjukan bahwa kompetensi sumber daya manusia memiliki pengaruh yang positif dan signifikan terhadap kualitas laporan keuangan pemerintah daerah. Artinya, semakin baik kompetensi sumber daya manusia pada SKPD Kabupaten Karangasem, maka semakin baik kualitas laporan keuangan pemerintah daerah yang diperoleh. Hasil penelitian ini didukung dengan penelitian oleh Nurrilah (2014) dan Roviyantie (2011) yang menyatakan kompetensi sumber daya manusia berpengaruh positif signifikan pada kualitas laporan keuangan daerah. Penelitian serupa yang dilakukan oleh Yosefrinaldi (2013), Ariesta (2013), Dellano dan Deviani (2013), juga menunjukkan hasil yang sejalan yaitu kompetensi sumber daya manusia berpengaruh positif pada kualitas pelaporan keuangan daerah. 
ISSN: 2302-8556

E-Jurnal Akuntansi Universitas Udayana

Vol.23.2. Mei (2018): 1253-1276

Hasil pengujian penelitian ini menunjukan bahwa sistem pengendalian intern berpengaruh positif pada kualitas laporan keuangan pemerintah daerah. Artinya, semakin baiknya sistem pengendalian intern yang diterapkan oleh SKPD Kabupaten Karangasem, maka kualitas laporan keuangan pemerintah daerah karangasem juga akan semakin meningkat. Hasil penelitian ini didukung dengan penelitian yang dilakukan oleh Nurillah (2014) yang menunjukkan hasil bahwa sistem pengendalian internal memiliki pengaruh positif pada kualitas laporan keuangan pemerintah daerah. Penelitian ini juga sejalan dengan hasil penelitian oleh Sugandi (2013) dan Yosefrinaldi (2013) yang memberikan hasil bahwa sistem pengendalian internal berpengaruh positif pada keterandalan laporan keuangan pemerintah daerah.

Komitmen organisasi menunjukkan sikap seseorang yang loyal terhadap organisasinya dan memiliki keinginan untuk memberikan hasil kerja yang terbaik bagi kepentingan organisasinya serta memiliki keinginan untuk berusaha mencapai tujuan organisasinya (Luthan, 2006:249). Semakin tinggi komitmen organisasi seorang karyawan maka semakin tinggi loyalitas karyawan terhadap perusahaan. Tingginya loyalitas maka diharapkan akan meningkatkan motivasi kinerja karyawan dan memiliki pengendalian internal dalam diri untuk memajukan organisasi yang dijalankan.

Hasil pengujian penelitian ini menunjukan bahwa komitmen organisasi berpengaruh positif pada kualitas laporan keuangan. Artinya, semakin tinggi komitmen anggota SKPD Kabupaten Karangasem, maka akan semakin baik kualitas laporan keuangan pemerintah daerah yang dihasilkan. Hasil penelitian ini didukung 
dengan penelitian yang dilakukan oleh Sugandi (2013) dan Nopprial (2015) yang menemukan hasil bahwa komitmen organisasi berpengaruh pada kualitas laporan keuangan pemerintah daerah.

Hasil pengujian penelitian ini menunjukan pemanfaatan teknologi informasi berpengaruh positif pada kualitas laporan keuangan pemerintah daerah. Artinya, semakin baik pemanfaatan teknologi informasi yang dilakukan oleh SKPD Kabupaten Karangasem, maka kualitas pengambilan keputusan terhadap laporan keuangan pemerintah daerah akan semakin maksimal. Hasil penelitian ini juga didukung dengan penelitian yang dilakukan oleh Indriasari (2008) dan Widyaningrum (2010) yang menunjukkan hasil serupa.

\section{SIMPULAN}

Berdasarkan tujuan penelitian, rumusan masalah dan hasil penelitian dengan pembahasan yang telah dipaparkan, maka dapat diambil kesimpulan dari penelitian sebagai berikut yaitu gaya kepemimpinan, kompetensi sumber daya manusia, sistem pengendalian internal, komitmen organisasi dan pemanfaatan teknologi informasi berpengaruh positif dan signifikan pada kualitas laporan keuangan pemerintah daerah. Berdasarkan hasil penelitian dan kesimpulan, maka saran-saran yang dapat diberikan adalah, saran bagi pihak pemerintah kabupaten/kota untuk peningkatan kualitas laporan keuangan, yakni dalam memberikan tugas didalam pekerjaannya sebaiknya seorang pimpinan mampu bekerjasama didalam melakukan pekerjaan karena berdasarkan hasil penelitian pada kuisioner masih banyak yang tidak setuju 
ISSN: 2302-8556

E-Jurnal Akuntansi Universitas Udayana

Vol.23.2. Mei (2018): 1253-1276

bahkan sangat tidak setuju dengan pilihan pimpinan memberikan semua pekerjaannya dan tanggung jawab kepada bawahan.

Sebaiknya seorang pemimpin ikut serta berperan dalam melaksanakan tugas tersebut karena gaya kepemimpinan yang diterapkan seorang pemimpin dalam melaksanakan tugasnya dapat memberikan pengaruh kepada bawahannya yang secara tidak langsung dapat mempengaruhi kinerja karyawan itu sendiri. Selain itu, kedisiplinan para pegawai dalam menaati peraturan yang berlaku juga perlu ditingkatkan, dengan cara menerapkan sanksi tegas kepada setiap pegawai yang melanggar aturan.

Berdasarkan hasil penelitian ini dapat diajukan saran kepada pihak pemerintah provinsi, kabupaten dan kota, yakni agar meningkatkan gaya kepemimpinan, kompetensi sumber daya manusia, sistem pengendalian internal, komitmen organisasi, dan pemanfaatan teknologi informasi yang sudah ada. Dengan adanya penerapan yang baik terhadap faktor-faktor diharapkan dapat meningkatkan kualitas laporan keuangan yang dihasilkan.

\section{REFERENSI}

Allen, N. J., and Meyer, J. P. (1990). The Measurement and Antecedents of Affective, Continuance and Normative Commitment to the Organization. Journal of Occupational Psychology, 63, 1-18.

Andini, Dewi. 2015. Pengaruh Kompetensi Sumber Daya Manusia dan Penerapan Sistem Akuntansi Keuangan Daerah Terhadap Kualitas Laporan Keuangan Daerah Pada Satuan Kerja Perangkat Daerah Kabupaten Empat Lawang Sumatera Selatan. Jurnal Ekonomi, Manajemen Akuntansi 1. Vol 24. No. 1 Hal. 65-82 
Badera, I Dewa Nyoman. 2008. Pengaruh Kesesuain Hubungan Corporate Governance Dengan Budaya Korporasi Terhadap Kinerja Perusahaan. Disertasi Doktor Ilmu Ekonomi Universitas Gadjah Mada.

Celviana, Widyaningrum, Rahmawati. 2010. Pengaruh SDM, dan Pemanfaatan Teknologi Informasi Terhadap Keterandalan Dan Ketepatwaktuan Pelaporan Keuangan Daerah Dengan Variabel Intervening Pengendalian Intern Akuntansi, Studi Empiris Di Pemda Subosukawonosraten. Simposium Nasional Akuntansi XII Purwokerto. Vol 23. No 1. Hal 125-156

Cherington, David J. 1998. The Management of Individual and Organization Perfomance, Organizational Behaviour. Brighman Young University

Chong, V. K. and K. M. Chong 2002. Budget goal commitment and informational effect of budget participation on performance: A structural equation modeling approach. Behavioral research in accounting. Vol 14. No 3. Hal.65-86

Dewi, N.P Erawati, 2014. Pengaruh Partisipasi Penganggaran, Informasi Asimetris, Penekanan Anggaran dan Komitmen Organisasi Pada Senjangan Anggaran. E-Jurnal Akuntansi Universitas Udayana.2013

Diani, Dian Irma. 2014. Pengaruh Pemahaman Akuntansi, Pamanfaatan Sistem Informasi Akuntansi Keuangan Daerah Dan Peran Internal Audit Terhadap Kualitas Laporan Keuangan Pemerintah Daerah (Studi Empiris Pada Satuan Kerja Perangkat Daerah Dikota Pariaman). Jurnal akuntansi. Vol. 2, No. 1

Hahn, M., Lawson, R., and Lee, Y. G. 1992. The Effect of Time Pressure and Information Load on Decission Quality. Psychology and Marketing, 9 (5) : 365-378.

Havesi, G.A 2005. Standards For Internal Control In New York State Goverment.

Heidjrachman dan Suad, Husnan, 2002, Manajemen Personalia, Badan Penerbit Fakultas Ekonomi (BPFE), Yogyakarta

Herniyasa, Hilma. Sri Fadilah \& Kania. 2014. Pengaruh Penerapan Gaya Kepemimpinan dan Good University Governance Terhadap Kualitas Laporan Keuangan. Jurnal Akuntansi Fakultas Ekonomi dan Bisnis Universitas Islam Bandung. ISSN 2460-2561

Hullah, A.R., Pangemanan S., Tangkuman , S. \& Budiarso, N. 2012. Pengaruh Sumber Daya Manusia dan Pemanfaatan Teknologi Infromasi terhadap 
ISSN: 2302-8556

E-Jurnal Akuntansi Universitas Udayana

Vol.23.2. Mei (2018): 1253-1276

Keterandalan Pelaporan Keuangan Pada Pemerintah Sulawesi Utara. Jurnal Riset Akuntansi, Vol 3- No. 2: pp. 9-21

Ikhsan, Arfan dan Muhammad Ishak, 2008. Akuntansi Keprilakuan. Salemba Empat, jakarta

Indriasari, Desi. 2008. Pengaruh Kapasitas Sumber Daya Manusia, Pemanfaatan Teknologi Informasi, dan Pengendalian Intern Akuntansi Terhadap Nilai Informasi Pelaporan Keuangan Daerah. Pontianak : Jurnal SNA. Vol VI. Hal 126-159

Indra Yudha Kusuma, Muhhamad. 2013. Analisis Faktor-Faktor Yang Mempengaruhi Tingkat Penerapan Akuntansi Akrual Pada Pemerintah. Jurnal Akuntansi Universitas Diponegoro 2(3), hal 1

Jogiyanto, H.M. 2006. Analisis dan Desain System Informasi : Pendekatan Terstruktur Teori dan Praktek Aplikasi Bisnis. Andi Offies. Yogyakarta

Kalbers, Lawrence P., and Forgarty, Timothy J. 1995. Professionalism Its Consequences: A Study Of Internal Auditors. Auditing: A Journal of Practice. Vol. 14. No. 1; 64-86

Karmila, 2012. Pengaruh Kapasitas Sumber Daya Manusia dan Sistem Pengendalian Intern Terhadap Keterandalan Pelaporan Keuangan Pemerintah Daerah (Studi Empiris Pada Pemerintah Kabupaten Riau). Jurnal Sorot. Vol. 9 No.1. tahun 2012

Khairina Nur, Izzaty. 2012. Pengaruh Gaya Kepemimpinan Dan Kualitas Sumber Daya Manusia Terhadap Penerapan Anggaran Berbasis Kinerja Badan Layanan Umum (Studi Pada Blu Universitas Diponegoro Semarang). Jurnal Akuntansi Universitas Diponegoro

Luthans, Fred. 2006. Perilaku Organisasi. Edisi Pertama. Terjemahan Vivin Andika Yuwono dkk. Yogyakarta:Andi

Mardiasmo. 2004. Akuntansi Sektor Publik. Yogyaakarta:Penerbit Andi

Maksyur, Noprial Valenra. 2015. Pengaruh Kualitas Sumber Daya Manusia, Komitmen Organisasi, Sistem Pengendalian Intern, Dan Pemanfaatan Teknologi Informasi Terhadap Kualitas Laporan Keungan (Studi Empiris Pada SKPD Kabupaten Indragiri Hulu). Jurnal Ekonomi. Vol 2, No. 2

Nawawi, Hadari. 2003. Kepemimpinan Mengefektifkan Organisasi. Yogyakarta: Gajah Mada University Press. 
Nouri, H. and R. J. Parker. 1996. The effect of organizasionalt commitment on relation between budgetary participation and budgetary slack. Behavioral research in accounting. Vol 8. Hal 74-90

Nurillah, As Syifa. 2014. Pengaruh Kompetensi Sumber Daya Manusia, Penerapan Sistem Akuntansi Keuangan Daerah (SAKD), Pemanfaatan Teknologi Informasi,dan Sistem Pengendalian Intern Terhadap Kualitas Laporan Keuangan Pemerintah Daerah (Studi Empiris Pada SKPD Kota Depok). Jurnal Akuntansi dan Bisnis. Vol. 1, No.1. Hal: 2337-3806.

Pamilih, Ismail. 2014. Pengaruh Independensi, Gaya Kepemimpinan,, Komitmen Organisasi Dan Pemahaman Good Governance Terhadap Kinerja Auditor Pemerintah. E-pirnts Universitas Muhammadiyah Surakarta,2(14), hal: 75-91

Ratifah, Ifa dan Mochammad Ridwan. 2012. Komitmen Organisasi Memoderasi Pengaruh Sistem Akuntansi Keuangan Daerah terhadap Kualitas Laporan Keuangan. Bandung: Trikonometika Vol 11, No. 1 Hal 29-39

Robins, Stephen P., Judge, Timothy A. 2008. Perilaku Organisasi. Jakarta: Salemba Empat

Roviyantie, Devi. 2012. Penagruh Kompetensi Sumber Daya Manusia dan Penerapan Sistem Akuntansi Keuangan Daerah Terhadap Kualitas Laporan Keuangan Pemerintah Daerah. Jurnal Akuntansi. Vol.4, No. 1. Hal 57-75

Sahertian, Pieter. 2010. Perilaku Kepemimpinan Berorientasi Hubungan Dan Tugas Sebagai Anteseden Komitmen Organisasional, Self- Efficacy dan Organizational citizenship Behavior (OCB).Jurnal Manajemen dan Kewirausahaan. Vol. 12, No. 2, 156-169

Sari, Shinta Permata dan Banu Witono. Keterandalan dan Ketepatwaktuan Pelaporan Keuangan Daerah Ditinjau Dari Sumber Daya Manusia, Pengendalian Interal dan Pemanfaatan Teknologi Informasi. Seminar Nasional dan Call For Paper (Sancall 2014): Research Methods And Organizatinal Study. Jurnal ISN 978. Hal 41-425

Saleh, Muhammad \& Venjte Ilat. 2012. Pengaruh Kualitas Sumber Daya Manusia, Pemanfaatan Teknologi Informasi dan Sistem Pengendalian Intern terhadap Keandalan Pelaporan Keuangan pada Perusahaan Dealer Mobil di Sulawesi Utara. Ejournal Unsrat. Vol 2, No 2. Hal 20-56

Schick, A . G., Gordon, L. A., and Haka, S. 1990. Information Over Load: A Temporal Approach. Accounting, Organizations and Society, 15 (3); 199220 
ISSN: 2302-8556

E-Jurnal Akuntansi Universitas Udayana

Vol.23.2. Mei (2018): 1253-1276

Setiawan, R.B. 2010. Pengaruh Gaya Kepemimpinan Terhadap Motivasi Kerja Pegawai Pada PT. PLN (Persero) Kantor Wilayah Sumatera Utara. Jurnal Manajemen Universitas Sumatera Utara

Setiyawati, Hari. 2013. The effect of internal accountans' competence managers' commitment to organizations and the implementation of the internal control system on the quality of financial reporting. Jurnal. Vol 2 No.11.pp 19-27.ISSN 2319-8028

Simanjuntak, Binsar H. 2010. Penerapan Akuntansi Berbasis Akrual di Sektor Pemerintahan Indonesia.Jakarta : Disampaikan pada kongres XI Ikatan Akuntansi Indonesia

Soimah, Siti. 2014. Pengaruh Kapasitas Sumber Daya Manusia, Pemanfaatan Teknologi Informasi, Dan Sistem Pengendalian Intern Pemerintah Terhadap Kualitas Laporan Keuangan Pemerintah Daerah Kabupaten Bengkulu Utara. Skripsi. Universitas Bengkulu

Stanburry, W.T 2003. Accountanbility to Citizens in The Westnnester Model Of Goverment: More Myth Than Reality. Fraser Institute Digital Publication: Canada

Sugandi, Joe. 2013. Pengaruh Kapasitas Sumber Daya Manusia, Pemanfaatan Teknologi Informasi, Pengendalian Intern Akuntansi, dan Komitmen Organisasi Terhadap Keterandalan Pelaporan Keuangan Pemerintah Daerah (Survei Pada SKPD se-Kabupaten Kuansing). Jurnal Akuntansi. Universitas Riau

Suwardjono, 2005. Teori Akuntansi : Perekayasaan Pelaporan Keuangan. Edisi Ketiga. BPFE, Yogyakarta.

Sugiyono. 2014. Metode Penelitian Bisnis Bandung : Alfabeta

Trisnaningsih, Sri. 2007. Independensi Auditor dan Komitmen Organisasi sebagai Mediasi Pengaruh Pemahaman Good Governance, Gaya Kepemimpinan dan Budaya Organisasi terhadap Kinerja Auditor. SNA X. Vol 7. Hal 120136

Tjiptoherijanto, Prijono., Soemitro, Sutyastie. 2001. Pemberdayaan Penduduk dan Peningkatan Kualitas Sumber Daya Manusia . Jakarta: Cita Putra Bangsa.

Uman, Khaerul. 2010. Perilaku Organisasi.Edisi Pertama. Bandung: Pustaka Setia 
Vandenberg, R. J., and Lance, C.E 1992. Examining the Central Order of Job Satisfaction And Organizational Commitment. Journal of Management, 18 : 153-167

Wati, Kadek Desiana. Nyoman Trisna Herawati. Ni Kadek Sinarwati. 2014. Pengaruh SDM, Penerapan SAP, Dan Sistem Akuntansi Keuangan Daerah Terhadap Kualitas Laporan Keuangan Daerah. Jurnal Akuntansi. Vol.2, No.1. Universitas Pendidikan Ganesha

Warren, S. Carl., and Reeve, M. James., and Fess, E. Philip. 2005. Corporate Financial Accounting. South Western: Thomson

Wentzel, K. 2002. The influence of fairness perception and goal commitment on managers performance in budget setting. Behavioral research in accounting. Vol 14. 247271

Wilkinson, W. Joseph, Michael J. Cerullo, Vasant Raval, \& Bernard Wong-OnWing. 2000. Accounting information system: essentil concepts and applications. Fourth edition. John wiley and sons. Inc

Winidyaningrum \& Rahmawati. 2010. Pengaruh Kapasitas Sumber Daya Manusia dan Pemanfaatan Teknologi Informasi Terhadap Keterandalan dan Ketepatwaktuan Pelaporan Keuangan Pemerintah Daerah Dengan Variabel Intervening Sistem Pengendalian Intern Akuntansi (Studi Empiris di Pemda Subosukowonosraten). Kumpulan Makalah Simposium Nasional Akuntansi XIII. Vol 9. Hal 89-115.

Yendrawati, Reni. 2013. Pengaruh Sistem Pengendalian Intern dan Kapasitas Sumber Daya Manusia Terhadap Kualitas Informasi Laporan Keuangan dengan Faktor Eksternal Sebagai Variabel Moderating. JAAI Vol. 17 No. 2. Hal 165-174

Yosefrinaldi, 2013. Pengaruh Kapasitas Sumber Daya Manusia dan Pemanfaatan Teknologi Informasi Terhadap Kualitas Laporan Keuangan Pemerintah Daerah Dengan Variabel Intervening Sistem Pengendalian Intern Pemerintah (Studi Empiris Pada Dinas Pengelolaan dan Aset Daerah SeSumatra Barat). Jurnal. Vol.1, No.1. 